DE DE GRUYTER

OPEN

\title{
JOINED AND RESPONSIBLE PARENTING
}

\section{Arta Selmani-Bakiu}

South East European University, Faculty of Law, arta.selmani@seeu.edu.mk

DOI: 10.1515/seeur-2017-0011

\section{Abstract}

In the contemporary family law, parents are obliged to arrange the joined implementation of the parenting rights either by their own will or through the help of their lawyers and/or mediators. This institute of mutual agreement is known as joined custody or joined implementation of the parenting right after the divorce of the marriage. This institute makes it possible for parents who live separately to arrange their custody rights in the most convenient way for the child. With a joined custody agreement, the parents accept the obligation to implement all the rights and duties that constitute the parenting right even in case of their separation. Through not dividing their rights from their obligations and with the aim of being closer to the needs of the child, the institute of joined custody helps avoid the feelings of hostility and disagreement in regard to the judicial decision which gives permanent custody to one of the parents. This institute is incorporated in the family law of many countries (Sweden, Norway, Finland, Denmark, UK, France, Italy, Germany, Belgium, Switzerland, Hungary, Czech Republic, USA and Australia). This article aims to emphasize the need to introduce in the family law of RM an explicit provision for joined and responsible custody after the divorce in order to achieve the best interest of the child. There is a joined initiative of parents who live separately from their children who request the amendment of the Family Law of RM in this direction.

Keywords: joined custody, divorce, family law, child's best interest, Macedonia. 
Divorce does not mean the end of parenting (Moto of a public debate on Joined Custody)

\section{Introduction}

Parents who live together (in marriage or domestic partnership) presumably implement their parenting duties in mutual agreement and in children's best interest. Parents jointly decide about the rights and obligations of their underage children. They are mutually responsible for their education and for securing a healthy and decent life in accordance with their incomes and opportunities. Parents execute their parenting rights through contributing to the education of the children, supporting them, representing them and also through creating a convenient environment for the psycho-physical development of a healthy personality in order to enable them for an independent life. Thus, according to the principle of equality, parents execute their right and obligations:

"to ensure that family education includes a proper understanding of maternity as a social function and the recognition of the common responsibility of men and women in the upbringing and development of their children, it being understood that the interest of the children is the primordial consideration in all cases" (CEDAW, 1979, art. 5, par. 2).

Of course, during the execution of parenting rights by the parents who live together in marriage or domestic partnership there is no absolute power of one or the other parent and in argumentum a contrario, there is no absolute equality, thus the parents should act in bona fides to ensure a complete implementation of their parenting rights. In reality there are no textual and mathematical divisions of parenting rights and obligations. The law provides for equality in order to ensure equal opportunities for the parents, however, the objective is to equally implement the obligations that are in the best interest of the child.

Therefore, the issue of absolute joined custody in marriage that derives from the law, in reality has its own flexibility. It is not the matter of a strict schedule of acts that are to be fulfilled by the parents, instead, there are certain rights and duties that can only be implemented by one of the parents, but in a mutual agreement and understanding with the other parent. In this way, there are situations when only one parent is present within other people or institutions, but there is always the presumption of the agreement and presence of the other parent (Mandro-Bilalli et al., 2006, p. 601). 
However, there are situations in life that implicate the divorce of the parents. The divorce represents a legal process that terminates the joined life of two partners, however, this process does not mean in any way the termination of parenting. Parenthood continues after the divorce, despite the mutual problems and disagreements that the spouses might have. Inter-partner disagreements that contribute to divorce must not impact the continuity of parenthood towards the children. Moreover, the imposition of their own problems and the race for power among parents, puts the children in the status of victim which can have serious consequences in the further development of their personality.

Therefore, the introduction of the institute of joined custody after the divorce aiming at the child's best interest and sharing of the parenting care is crucial.

\section{Consequences of divorce for the children}

Throughout history, children have been separated from one or both living parents by business, travel, and war. Yet, permanent separation by conscious design can be a complicated, complex, and stressful situation. One judge who makes such determinations has emphasized the frustrations inherent in the custody determination process by stating, "under the best of circumstances it is a task requiring Solomonic judgment." (Siebel, 2006, p.213)

According to a different historical analysis, children of traditional families have not been exposed to the social dynamics of modern families. Many authors agree that in the traditional societies there was no awareness about the special meaning of the childhood age, about the need for protection, care and cultivation of children; these concepts have developed in the modern family (Мицковиќ, 2008, p.63).

Nowdays children take important part in the decision-making process in regard to their interests, thus they are also actors in family problems. Taking into consideration that modern parents show a great deal of interest towards their children they may not be aware that they also indirectly involve them in their mutual problems.

Therefore, the evolution of the family concept and the increase of the economic independence contributed to the rise of the awareness that "it is better to have a reasonable divorce than a stressful marriage with problems".

Spouses should be educated that their life has a positive future even after the divorce so that this attitude can also be transferred to the children. Children should not be exposed to mutual problems of their parents and must not in any way be challenged to choose which parent is better than the other. 
Since both adults share responsibility for the continued welfare of their children, divorce only ends their former relationship as partners, but not their future relationship as parents. To continue to fulfill this joint commitment, they must "remarry" as parents who still share a common interest in their children, keeping that commitment foremost and subordinating personal differences in their relationship. "We saw things differently in marriage, and those differences have only grown since the divorce. We're not in the business of criticizing or changing each other's values. But we are in the business of translating our respective values into what we each want, and then negotiating those wants so we can reach a joint decision for the sake of the kids" (Pickhardt, 2005, p.17).

The consequences of the divorce for the children depend on the judicial decision which determines with which parent they will continue to live, the manner in which their relations will be regulated, the direct contacts with the other parent as well as the alimentation value. Keeping personal contacts and not paying the alimentation are the main problems that appear between the actors of the post-divorce process (parents and children).

According to all legislative provisions and international documents, the entire divorcing procedure should aim at preserving the serenity of children in order to avoid their involvement into the conflict among their parents.

\section{Problems in regard to implementing the right of the parents to visit the child who does not live with them}

Custody refers to the post-divorce or post-separation living arrangements of the minor child. The parent who has custody typically has responsibility for supervision of the child and for meeting the child's daily needs. Custody is not necessarily exclusive. The other parent may have input into decisionmaking regarding the child's education or religious training, for example. The non-custodial parent may also have actual physical custody of the child for agreed-upon periods of time. Whether this is characterized as visitation or joint custody depends on the laws of the jurisdiction in which it is ordered and on the intention of the parties. Visitation generally refers to briefer periods of time (during summer vacations, for example), while joint custody refers to a more equal balance of responsibility (Stark, 2005, p. 182).

According to our legal framework, the judicial decision on divorce includes the decision for the visitation of children for the non-custodial parent. In cases when the parents have not agreed on this issue or their agreement does not meet the interest of the children, taking into consideration the opinion of the 
Center for social care, the Court will decide if the children will reside with one of the parents, if some of them will reside with one and the others with the other parent, or if they will be transferred to a third institution (The Law on Family, art. 80). Furthermore, the Court will also decide on the custody and education of children in cases of annulment of marriage or in cases of confirming or contesting the parenthood of one of the parents. The noncustodial parent is entitled to maintain personal relationship and direct contact with his/her children, if the Court has not decided differently in regard to their best interest. Upon the request of one of the parents or the Center for social care, the Court can revise the decision on custody and education of children and on the relationship between the divorced spouses and their children if the circumstances demand so (Ibid. par.3).

It is very convenient for the parents, children and the competent state institutions if the parents succeed to agree on the issue of custody. Such a collaboration and mutual understanding represents a reasonable conclusion of the post-divorce situation. In that way, they would still be able to decide in common and independently in regard to the implementation of parenting rights, they would guard the responsibility for the destiny of their children as well as they would limit the partnership relations from the parenting relations, which enables them to develop healthy relations with their children even after the divorce (Стручни методолошки упатства и прирачници -Документи, 2007, p. 220).

The successful negotiation and agreement between the parents in regard to custody and the mutual relationship with their children avoids the feeling of loss or bereavement of the child for the non-custodial parent. At the same time, the parent who has the custody becomes aware that maintaining personal contacts between the child and the other parent is of great interest for the normal development of the child, moreover, preserving that relationship is not a matter of their own will, instead it is a legal right of each of the parents and also the right of the child (Ibid.).

In this aspect, it is very important to emphasize the crucial role of the Centers for social care, which bring decisions that regulate the manner and the dynamic of the implementation and maintenance of regular personal relations and direct contacts between non-custodial parents and their children. The entire procedure before the Centre for social care deserves a special critique due to the lack of balance that it shows towards the rights of the parents and the children and because of incorrect implementation of the provisions of the Law on Family. 
However, despite the existence of a rich legal source for the regulation of the competences and duties of the organs and institutions in Republic of Macedonia that ought to secure unimpeded contacts within the children and their non-custodial parents, there are many problems that occur. Namely, the legal practice shows that persons who need to fulfill this right encounter serious problems while implementing it, especially if the parent who has the permanent custody deliberately decides to obstruct this right. Problems can appear in the lack of respect for the positive provisions of the law through not appointing executors of the decisions on personal contacts brought by the Centre for social care. Furthermore, it can be concluded from the way in which the eligible institutions operate that they either do not know their own competences and limits of their operation or they are not well systematized and concrete in order to properly achieve their objectives. As a separate problem of their acting is the lack of team work, the inappropriate technical support as well as the lack of coordination between the competent institutions - the centers for social care, the Ministry of Labor and Social Policy (MLSP), the Ministry of Interior Affairs (MIA) and the Courts - through clearly defining the competences and acting procedures (Најденова-Левиќ- lawyer, 2014).

The restriction of this very important right and obligation is not only a discrimination towards the parent who does not have permanent custody, it also has serious consequences of manifestation of power and authority by the parent the child lives with. In this regard, the problem with the parent who has custody over the child and acts as he/she has the monopoly towards him/her should also be dealt with. There are many cases evident in the judicial practice where the parent who has custody completely obstructs the implementation of the judicial decision in regard to the right to visitation for the non-custodial parent. According to the Criminal Code of RM (CCRM, 1996, art. 198, par.1), this act of obstruction by the parent who has custody over the child is treated as a criminal act:

"He who illegally will kidnap an underage person or obstructs him from being with the person he has a right to be with, will be punished by a fee or by up to one-year imprisonment. In accordance with paragraph 3 of this article, if the Court decides for a parole, it can order the perpetrator to bring back the underage person, or can enable the execution of the executive decision in regard to the custody of the underage person". 


\section{The need to introduce a specific provision on joined and responsible custody after the divorce}

The agreement between the parents on joined custody after the divorce is identified by many terms. In the English terminology it is known by the concepts of "child custody" and "child custody and visitation" agreements. Since these agreements cover wider issues than custody and visitation, it is thought that "parenting agreements" or "parenting plans for the benefit of the child" would be the most appropriate terms.

Despite the terminology used by national courts, parenting agreements usually cover the following issues:

- Who will be in charge of the child-care?

- How will the former spouses reach an agreement regarding their children?

- How will the children spend time with each of the parents and other persons important to them?

- How will the parents meet their children's medical, emotional, educational, spiritual, physical and social needs? (Zemmelman, 2014, p.28)

The legislation of RM does not contain specific provisions that regulate the time limits of the non-custodial parent's visitation to his child, nor does it provide the strict amount of the alimentation to be paid. According to the judicial practice, the usual amount decided for the alimentation is $30 \%$ of the income of the parent. These gaps in the law result in different and inappropriate interpretations. Therefore, there is an immanent need for amending the current law in order to emphasize the equality between parents after the divorce, to contain a specific provision on joined custody, to provide for a mutual agreement between parents on jointly raising and educating the child that would be monitored by the Centre for social care which should alert the Court for all the cases when one parent executes the parenting right contrary to the interests of the child.

According to the current law, the agreement between the parents should de iure enable them to jointly agree to continue executing their parenting right or custody or to give custody to one of the parents, provided that the Court decides whether that agreement meets the best interest of the child. However, in reality this situation is very different in regard to the implementation of such an agreement.

Parents themselves need to believe that although they are no longer spouses, however, they will remain parents of their children for the rest of their lives. Many cases prove that this approach is not quite understood and shared by the 
divorcing partners. What brings parents together in the same line of thinking and acting, once they are divorced, is their children, therefore, any kind of attempt to overrule the other parent and to involve in a race which of them is the most powerful, cannot be justified in any way. Couples that live through these crises usually are not able to reach reasonable decisions. If the law is considered, the divorce should not interfere with the parenting rights and obligations of the parents towards their children. The problems occur when these legal provisions ought to be implemented in practice. Every divorced couple is specific and different in their own way, thus there is not a unique, "fits all" model that can be used in all cases as provided by the law. In this regard, the crucial role is played by the professional teams of the Center for social care who counsel and observe the divorced couples and their underage children.

Taking into consideration the fragility of the concept of divorce, the practice shows that the cases when the parents reach reasonable and timely agreements in regard to custody are very rare. In cases when the parents cannot agree, the Court decides on the issue of custody (Law on Family, Art. 80, par. 2-3). This certain provision clarifies that the Law on Family in RM does not include the institute of joined custody after the divorce, hence currently there is no legal ground for the Court to decide to give custody over the children to both of the parents at the same time.

\section{Initiative for introducing an explicit clause on joined custody}

Because of the problems that appear in the post-divorce period especially for the parents who do not receive custody by the judicial decision, different initiatives have been undertaken aiming to raise the awareness about a full capacity parenthood and to inspire the lawmakers to amend the Law on Family, especially the part dealing with the custody.

One of these initiatives was initiated by the academic community. Professor Dejan Mickovic from the Faculty of Law, UKIM, Skopje, suggests the introduction of an Explicit provision for the concept of responsible parenting and intensive communication with both parents.

For the professor there is no doubt that the parents must agree to continue to execute their parenting rights after the divorce, and in order to enable them to do so, the Law on Family needs to have that "explicit provision" that will regulate the concept of joined and responsible custody.

"This provision exists in all European legislations. Joined execution of the 
parenting right after the divorce means jointly making all the important decisions related to the rights and the interests of the child. All research results prove that the children need the intensive presence of both their parents in their life", indicates Mickovic. He warns that the main problem appears in the visitations that the non-custodial parent needs to have with his/her child and there are many cases in the practice that indicate this. He highlights that when one of the parents gains custody over the child, this does not mean that the other parent should be completely excluded from the live of the child since this is not justified neither in the legal nor in the psycho-social aspect (Мицковиќ, Akademik, 2016).

The other initiative was initiated by a group of parents who also requested joined custody after the divorce.

"The main objective of the initiative of the group of parents for the introduction of a 50-50 equally divided or joined custody is to change the current unjust position of the parents in regard to custody after divorce. The preserving concept of one main parent (in absence of a mutual agreement which is very hard to be reached) who receives full custody of the children and their education, and an additional parent who has a very limited time to implement a qualitative parenting, is first of all harmful to the children who de facto lose one of their parents. Therefore, this group of parents suggests a new concept in which both of the parents, after the divorce, will continue to have equal rights and obligations towards their children, same as when they were married" (Рибароски, 2015).

In January 2016 there was a public debate in regard to the Initiative on joined custody which was followed by representatives from relevant state institutions, NGOs, members of the academic and expert community, psychologists, professors, lawyers and a large number of interested parents who publicly expressed their views, suggestions and experiences in reference to the need for concrete legal amendments (Public debate of January 28, 2016). The conclusions of this debate provide that there is need for immanent changes in the Law on Family in order to enable parents to share the parenting and custody in case of their divorce. The need to raise the public awareness on this issue is also mentioned in the conclusions with the aim to preserve the interest of children in accordance with the legal practice and the international standards provided by the European Court of Human Rights.

The concept of joined custody is also supported by the Judge Radmila Karanovic, who has a long experience in family law cases and indicates that each of these very complex cases is a very different and unique story. She 
states that "parents should continue to implement their parenting rights after the divorce and should continue to decide on important matters jointly and in mutual agreement. Implementation of joined custody and agreed parenting even after the divorce will implicate a more complete regulation of parenting relations as well as will help the children to get used to the new and changed circumstances and avoid the conflict between former spouses. However, in order to implement the concept of joined custody and responsible parenting, there is a need for numerous changes in the legal provisions as well as changes in the way of working of the Centers for social care, with the aim of preserving the interest of the child" (Карановиќ, 2016).

Dragi Zmijanac (Director \& Founder of the First Children's Embassy in the World Megjashi), also arguments in accordance to the introduction of the joined custody:

"The initiative on legal amendments in order to incorporate the concept of full capacity parenting for both parents after the divorce aims to enable the parents to share their care for the child. The benefits are in the interest of the children since they immanently need care from both parents and it is also suggested by the recommendations of the Committee for the rights of the child in order to find the best solution for the child who is found in the conflict zone between the parents who cannot agree on the issue of custody. Eligible courts, expert teams in Centers for social care, while assessing in regard to the custody over the child should take into consideration the position that both parents should directly and jointly decide on their parenting rights (Змијанац, 2016).

Apart from introducing an explicit legal provision in the Law on Family and in accordance with the need to introduce and strengthen the institute on joined custody, Republic of Macedonia needs to ratify the European Convention on Contact concerning Children (15.V.2003), which provides the general principles of regulating the decision making process in regard to contacts concerning children. This convention also verifies the measures to be taken to ensure a regular implementation of contacts with children and returning them after the time spent together. It is very important that the Convention provides security measures which are to be taken if the visitation agreed-upon time is not respected. The Convention provides that these measures are in the competence of the Court.

In regard to the quality time which the child spends with the parent he lives with, there is an interesting definition on joined custody given in an international conference held in Bon (International Conference on Shared Parenting, 
December 2015): "Shared parenting — being defined as encompassing both shared parental authority and shared parental responsibility with a minimum of one-third time with each parent, including weekday time - is a viable post-divorce parenting arrangement for the majority of children of divorce, and in their best interests. The above apply to the majority of children and families, including conflict families, but not to situations of substantiated family violence and child abuse", Prof. Sünderhauf stated. "Thus national family law should at least include the possibility to give shared parenting orders, even if one parent opposes it." "Nevertheless, an accessible network of family relationship centers that offer family mediation and other relevant support services are critical in the establishment of a legal presumption of shared parenting, and vital to the success of shared parenting arrangements".

Thus, in order to prevent the problems that may appear and may destabilize the normal development of the child, it can be emphasized that:

The joined custody would mean a stable behavior and solid relation between the divorced parents in regard to their children. Introducing this provision in the Law on Family would guarantee:

- Full capacity parenting after the divorce,

- Equivalent care by both parents,

- Education and supervision of the parenting right with the aim that both parents are at the same position by enabling them to jointly and directly decide on important issues related to the interest of the child,

- Both parents would have the same access towards their children, none of them would be in a position of power or ruling over the parenting right of the other.

\section{Comparative approach on the institute of the joined custody}

The principal of maintaining personal relations and direct contact derives from the most important document on the rights of the child and that is the Convention on the Rights of the Child (1989) Article 9 paragraph 3 of this Convention implies that States Parties shall respect the right of the child who is separated from one or both parents to maintain personal relations and direct contact with both parents on a regular basis, except if it is contrary to the child's best interests. National legislations, although emphasizing the importance of the joined parenting after divorce, still have not been able to find a unified model of this kind of parenting.

Many jurisdictions make continuing contact a statutory right of the child (as, for example, in Austria, Belgium, France, Germany, Hungary, Italy, 
Lithuania, Netherlands, Norway, Russia, Slovakia, Spain and Sweden). Other States make it a statutory right of the parent (as, for example, Bosnia and Herzegovina, Denmark, Estonia and Greece). Still other jurisdictions, notably Bulgaria and England and Wales, do not legislate in terms of rights, but in practice their legal systems are predisposed to maintaining contact between child and parents and will require cogent evidence of harm to the child that outweighs the fundamental need of the child to have an enduring relationship with both parents, before denying contact.

Some States regard it as an obligation of the parent: (a) not to hinder contact between the child and the other parent (as in Estonia and Greece) and (b) to see the child (as in Bosnia and Herzegovina, France, Germany and Portugal), though few are prepared to impose sanctions on an unwilling parent who refuses to see their child. An outstanding exception to this position is Portugal where parents can be fined for refusing to see their children and France where a tortious action might lie (Lowe, 2009, p. 26). None of the jurisdictions surveyed distinguish contact rights upon the basis of the parents' marital status, although Belgium and the Netherlands make some distinction between parents with and without parental responsibility. In all jurisdictions, in cases of dispute, contact issues can be determined by the court upon the basis of the child's welfare (Ibid., p.27).

In the European perspective, taking into consideration the importance of the best interest of the children and their stable physical and mental development after the divorce of their parents, there are many international documents that explicitly regulate the right of the child to continue direct contacts with the non-custodial parent:

- The Convention on the Rights of the Child (1989),

- The European Convention on Human Rights (1950),

- The European Convention on Recognition and Enforcement of Decisions concerning Custody of Children and on Restoration of Custody of Children (1980),

- The Hague Convention on the Civil Aspects of International Child Abduction (1980),

- The European Convention on the Exercise of the Children's Rights (1996),

- The Hague Convention on Jurisdiction, Applicable Law, Recognition, Enforcement and Co-operation in respect of Parental Responsibility and Measures for the Protection of Children (1996),

- The Charter of Fundamental Rights of the EU (2000) (see article 24 - Children shall have the right to such protection and care as is necessary for their well-being. They may express their views freely. Such views shall 
be taken into consideration on matters which concern them in accordance with their age and maturity. In all actions relating to children, whether taken by public authorities or private institutions, the child's best interests must be a primary consideration. Every child shall have the right to maintain on a regular basis a personal relationship and direct contact with both his or her parents, unless that is contrary to his or her interests),

- The Convention on Contact concerning Children (2003),

- Brussels IIa Regulation concerning jurisdiction and the recognition and enforcement of judgments in matrimonial matters and the matters of parental responsibility (2003).

The family law of the European Union slowly but surely becomes a part of the legal order of all European countries in which the national courts are obliged to implement the European mechanisms in regard to the right to joined custody and the right of the child to take part in the decision-making process related to joined custody.

\section{Conclusion}

The right to maintain contacts with children as well as the limitations of this right represents a globally recognized discussion that concerns many national legislations. In order to regulate this issue of the parenting right, member states of the Council of Europe have adopted the Convention on contact concerning children. There are many problems that occur while implementing this right, therefore, many parents are denied of their fundamental right to have any kind of contact with their children. Judicial cases on this matter can last very long and can create further problems in regard to the implementation of judicial decisions. Moreover, the internationalization of family law implicates implementation problems that are linked to differences in legal systems, languages and cultures. The Convention aims to improve certain aspects of the right to preserve contact with children. This right can also be extended to other persons, especially if the child has already created family bonds with them. The aim is to ensure suitable protecting measures in order to ensure that the child is brought back safely after the agreed-upon visitation time (Самарџић, 2015, p. 826).

Although many legislative solutions for jointly implemented custody have been adopted, the situation with visitation of children remains a concern in many states in the world. Many international initiatives that have been raised are expected to give their results. In this occasion, one needs to mention the action of the Council of Europe to prepare the Draft Recommendation 
on the Rights and Legal Status of Children and Parental Responsibilities. Article 23 of this Draft Recommendation states that "Parental responsibilities should in principle belong to each parent. In cases where only one parent has parental responsibilities by the operation of law (ex lege), states should make procedures available for the other parent to have an opportunity to acquire parental responsibilities, unless it is against the best interests of the child. Lack of consent or opposition by the parent having parental responsibilities should not as such be an obstacle for such acquisition. The dissolution, termination or annulment of the parents' marriage or termination of other formal relationship, or their legal or factual separation should not as such constitute a reason for terminating by operation of law parental responsibilities".

As explained in the previous subtitles, the judicial practice of RM indicates that parental revenge creates situations of "kidnaping" one's own child and depriving him/her of contacts with the other parent. The concept of custody over the child is misinterpreted by many parents who believe that when they divorce they also must divide the children from their parent. A typical case of this kind is Mitovi v. Republic of Macedonia before the ECHR of April 16, 2015.

From the thoughts and views explained above, the following conclusions and recommendations can be drawn:

\section{Conclusions}

- The parenting right should be implemented in accordance with three basic principles: equality of parents, joined responsibility for the education, raising and development of the child, and prohibition of the abuse of the parenting right.

- Republic of Macedonia as a signatory to the Convention on the Rights of the Child has not fully and appropriately implemented the principle of joined and responsible parenting in its family law, hence, reforms and amendments of the Law on Family are urgently needed on this matter.

- A special critique is emphasized in the part of executing parenting rights in the post-divorce period. In RM there exist eligible state institutions that ought to ensure the unimpeded implementation of personal contacts and visitations between the children and their non-custodial parents, however, there are problems that occur with the parents who have custody over their children. Impeding the implementation of this fundamental right and obligation does not only discriminate the other parent, instead, it also impacts negatively the child in reference to the manifestation of power and authority from the custodial parent. In many separated families the concept of dividing the children after the divorce prevails, which very often provokes 
the other parent to "kidnap" his/her own child.

- In order to maintain a healthy psycho-physical development of the children, separated parents must not in any way involve them in their mutual conflicts. Maintaining a stable parenting is an assurance that the child will better cope with the separation and divorce.

\section{Recommendations}

- Inclusion of the institute of joined custody in the family law legislation through an explicit provision which will provide for joined and responsible execution of parenting rights when parents live separately;

- Compliance of the national family law legislation with the European and international regulations in order to ensure that parenting is executed in accordance with child's best interest. Introduction of an explicit provision for supervision of the implementation of the principle of respecting the child's best interest as a fundamental care of the parents in one hand and the secondary obligation to guard that interest for the state institutions.

- Introduction of family mediation and strengthening of marital and parental counseling. Mediation as an independent profession can contribute to finding peaceful solutions to family problems. The judicial procedure itself is very stressful and exhausting, especially in family and parenting cases. Mediation experts can contribute in easier solving of divorce issues. Expert counseling and mediation can contribute for a better agreement between the parents on important issues regarding their children, parents can agree on their future plans and can spare their children from the conflict situations in courtrooms.

- Including psychologist and professional social workers in the divorcing and post-divorcing process can be of benefit in two ways: firstly, they can help the children to better handle the turbulent period of their parents' divorce and secondly, they can help the spouses to avoid inter-partner competitions about their children and custody.

\section{References}

- Lowe,N (2009) A Study into the Rights and Legal Status of Children Being Brought up in Various Forms of Marital or Non-marital Partnerships and Cohabitation. Strasbourg: Councile of Europe

- Mandro-Bilalli,A; Meçaj,V; Zeka,T; Fullani,A. (2006). E drejta familjare. Tirana

- Мицковиќ,Д. (2008) Семејството во Европа XVI-XXI век. Skopje: Blesok

- Pickhardt, C.E (2005) The Everything Parent's Guide To Children And Divorce: Reassuring Advice to Help your Family adjust. Avon, Massachu- 
setts: Adams Media

- Siebel, C.C (2006) "Fathers and Their Children: Legal and Psychological Issues of Joint Custody." Symposium on Fathers and Family Law. American Bar Association. p.213-236.

- Stark,B. (2005) International Family Law- An Introduction. Burlington: Ashgate Publishing Company

- Самарџић, С.О (2015) «Регулатива породичног права намеѓуународном и европском нивоу са посебним освртом на право детета на здравље.» Дете у породичном праву - компаративни и међународно-правни аспект- пројект финансиран од Покрајински секретаријат за науку и технолошки развој АП: р.813-838.

- Zemmelman, M.L (2014) Building a Parenting Agreement That Works: Child Custody Agreements Step by Step- 8th Edition. California: NOLO

- The Law on Family of Republic of Macedonia.(2015) Consolidated Version

- Criminal Code of Republic of Macedonia, Official Gazette of RM no. 37/1996

- The Convention on Contact concerning Children (2003): http://www.coe. int/en/web/conventions/full-list/-/conventions/rms/090000168008370f

- Convention on the Rights of the Child (1989):http://www.ohchr.org/Documents/ProfessionalInterest/crc.pdf

- The Convention on the Elimination of All Forms of Discrimination against Women-CEDAW, (1981) : http://www.un.org/womenwatch/daw/cedaw/ cedaw.htm

- The Charter of Fundamental Rights of the EU (2000): http://eur-lex.europa.eu/legal-content/EN/TXT/?uri=CELEX:12012P/TX

- Draft Recommendation on the rights and legal status of children and parental responsibilities (2010): http://www.coe.int/t/DGHL/STANDARDSETTING/FAMILY/CJ-FA-GT3\%20 2010\%202\%20Rev\%203E\%20 -\%20draft $\% 20$ instrument $\% 20$ October $\% 20$ meeting\%20LA.pdf

- International Conference on Shared Parenting (2015) Best Practices for Legislative and Psycho-Social Implementation, Bonn, Germany: http:// twohomes.org/

- Стручни методолошки упатства и прирачници - Документи (2007) Јавна Установа- Завод за социјални дејности Скопје

- Public debate for Join Custody (2016) http://www.akademik.mk/razvodot-na-brakot-ne-znachi-prestanok-na-roditelstvoto-roditelite-treba-odgovorno-i-ednakvo-da-se-grizhat-za-deteto/

- Карановиќ, P - Judge of primary Court 2-Skopje (Interviewer - Arta Selmani-Bakiu), 22 June 2016

- Змијанац,Д- Director \& Founder of the First Children's Embassy 
in the World Megjashi- Skopje ( 2016): https://www.youtube.com/ watch? $\mathrm{v}=\mathrm{wVBxWT9FOnU \& \text {feature } = \text { youtu.be }}$

- Најденова-Левиќ, Н- lawyer, (2014) “Проблеми во остварувањето на правото на видување на детето со родителот со кој не живее.” (Масеdonian Centre for EuropeanTraining):http://www.soros.org.mk/CMS/ Files/Documents/Problemi_vo_ostvaruvanje na pravoto na viduvanje. $\underline{\mathrm{pdf}}$

- Akademik- Академик (2016): http://www.akademik.mk/profesorite-predlagaat-koreniti-reformi-vo-semejnoto-zakonodavstvo-roditelska-odgovornost-za-najdobar-interes-za-deteto/

- Рибароски, Н (Академик, 2015). РОДИТЕЛИ БАРААТ ИЗМЕНИ НА ЗАКОНОТ ЗА СЕМЕЈСТВОТО: Заедничко старателство и одговорно родителство и по развод: http://www.akademik.mk/roditeli-baraat-izmeni-na-zakonot-za-semejstvo-zaednichko-staratelstvo-i-odgovorno-roditelstvo-i-po-razvod-3/

- Case of Mitovi V. The Former Yugoslav Republic of Macedonia. European Court of Human Rights (16.04.2015) 